\title{
Emplacement age and PGE geochemistry of lamprophyres in the Laowangzhai gold deposit, Yunnan, SW China
}

\author{
WANG Jianghai (王江海) ${ }^{1}$, QI Liang (漆 亮 $)^{2}$, YIN An (尹 安) ${ }^{3}$ \\ \& XIE Guanghong (解广轰) 1 \\ 1. Guangzhou Institute of Geochemistry, Chinese Academy of Sciences, Guangzhou 510640, China \\ 2. Institute of Geochemistry, Chinese Academy of Sciences, Guiyang 550002, China; \\ 3. Department of Earth \& Space Sciences, University of California, Los Angeles, CA 90095, USA \\ Correspondence should be addressed to Wang Jianghai (email:wangjh@gig.ac.cn)
}

Received July 16, 2001

\begin{abstract}
Widely-distributed lamprophyres in the Laowangzhai gold deposit were associated closely with gold ores. Phlogopite ${ }^{40} \mathrm{Ar} /{ }^{39} \mathrm{Ar}$ dating suggests that the emplacement age of lamprophyric magma ranges from $(30.8 \pm 0.4)$ to $(34.3 \pm 0.2) \mathrm{Ma}$, and gold mineralization took place at $(26.4 \pm 0.2)$ Ma. PGE geochemical tracing indicates that gold in the gold deposit did not come from the primitive lamprophyric magma. The tempo-spatial paragenesis between lamprophyres and mesothermal gold deposits along the Jinsha-Red River belt may be attributed to the fact that they formed in the same tectonic setting.
\end{abstract}

Keywords: thermochronology, PGE geochemistry, lamprophyre Laowangzhai gold deposit, Yunnan.

The Laowangzhai super-large gold deposit was found in the Ailao Shan fault belt at the end of the 1980s. This deposit includes five ore segments i.e. Langnitang, Donggualin, Laowangzhai, Taqiaoqing and Dukumu (fig.1). Tempo-spatially, widely-developed lamprophyres in this gold deposit were associated closely with gold ores. Most of lamprophyres are minette, and the others are plagioclase-bearing minettes. Systematic studies have been done on the origin of the Laowangzhai gold deposit and related lamprophyres. For instances, $\mathrm{He}^{[1]}$ considered that the lamprophyres were derived from partial melting of the mantle, and emplacement may be later than gold mineralization. Huang et al. ${ }^{[2]}$ established a comprehensive model for the genesis of lamprophyres and concluded that the lamprophyres underwent a higher-than- $200^{\circ} \mathrm{C}$ hydrothermal alteration during 22.7-27.1 Ma after intrusion. Bi et al. ${ }^{[3]}$ indicated that the ESR ages for gold-bearing quartz (37.9-54.2 Ma) represented the time of gold mineralization. Hu et al. ${ }^{[4]}$ suggested that the mineralizer for gold mineralization was a sulfur-rich and deep-derived fluid, gold in gold ores came from their wall-rocks via extraction of a sulfur-rich mineralizer, and deeply-derived fluids may enter the mineralizing system in Cenozoic emplacement of lamprophyres and regional alkali-rich intrusive rocks.

Obviously, there is a general consensus in three aspects: (i) Both gold mineralization and lamprophyre intrusion occurred in the Cenozoic time. (ii) Gold mineralization was closely related 
to emplacement of lamprophyres and alkali-rich intrusive rocks. (iii) The magma activity provided an important power for gold mineralization, and induced addition of a sulfur-rich mineralizer to the gold mineralizing system. There are still many unsolved problems. The major issues include: (i) How young is gold mineralization in the Laowangzhai gold deposit? We cannot answer this question only according to the previous age data, because the published chronologic data not only have a great variant range, but also there is an unsuitable choice of dating methods. For example, $\mathrm{Pb}$ model ages were adopted as the mineralizing time for young gold deposits ${ }^{[5]}$. ESR dating is usually applied to touaternary researches. Its suitable dating scale ranges from several centuries up to many hundred thousand years. The upper time-limit of this dating method may be several million years ${ }^{[6]}$. If its appropriate scale is exceeded, the obtained ages will be unreliable ${ }^{[3]}$. (ii) Did the lamprophyres provide gold mineralization with gold? Was gold in lamprophyres enriched primitively or secondarily? Based on the previous result of elemental and isotopic tracing, it is difficult to remove the possibility that gold in gold ores did not come from adjacent lamprophyres ${ }^{[2]}$. Although Huang et al. ${ }^{[7]}$ designed a high- $T$ and high- $P$ experiment to show that a lamprophyric magma could not have carry enormous gold for gold mineralization, their experimental result is still not able to answer the question as to whether the lamprophyres provide gold for gold mineralization in the Laowangzhai gold deposit, due to too high a gold content $(2.5 \%)$ in the experimental sample. In this paper, we first present high-quality ${ }^{40} \mathrm{Ar} /{ }^{39} \mathrm{Ar}$ and PGE data, and then discuss the time of lamprophyre intrusion and gold mineralization, and mechanisms of gold enrichment in lamprophyres.

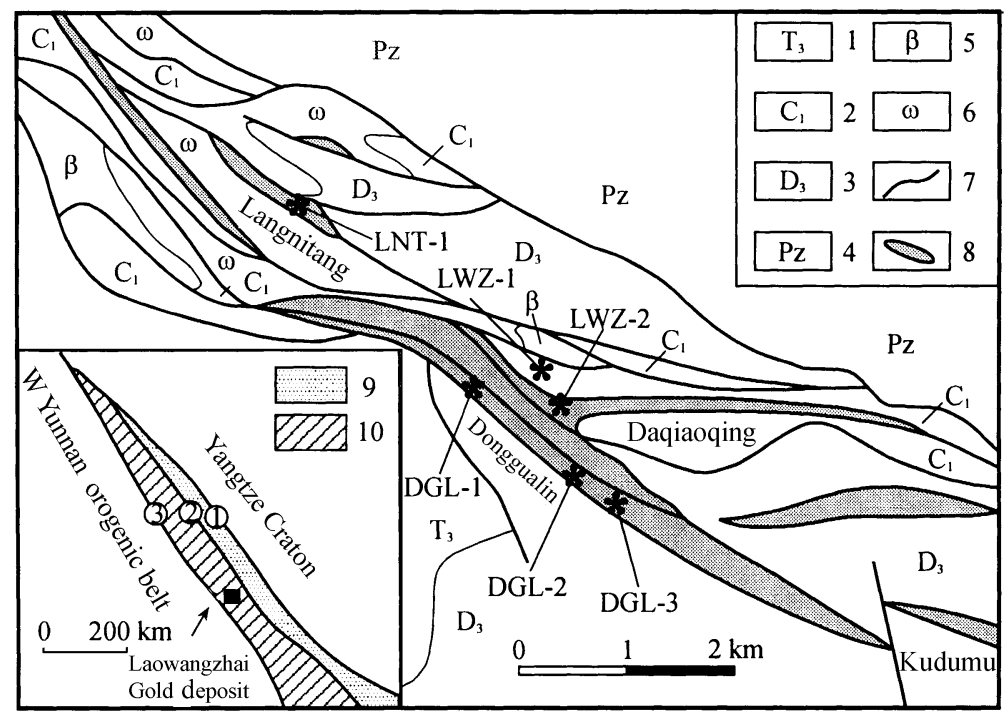

Fig. 1. Simplified geological map in the Laowangzhai gold deposit, illustrating the geologic setting and sampling localites (Modified after ref. [1]). 1, Upper Triassic; 2, Lower Carboniferous; 3, Upper Devonian; 4, Palaeozoic sedimentary rocks; 5 , mafic volcanic rocks; 6 , ultramafic rocks; 7 , faults; 8 , ore-hosted faults and magmatic rocks composed of lamprophyres and granitic porphyries; 9, Ailao Shan high-grade metamorphic belt; 10, Ailao Shan low-grade metamorphic belt; (1)Red River fault; (2)Ailao Shan fault; (3)Jiujia-Mojiang fault. 


\section{Experimental methods}

The relatively fresh minettes and plagioclase-bearing minettes were used for ${ }^{40} \mathrm{Ar} /{ }^{39} \mathrm{Ar}$ dating and PGE analyzing, but sample LWZ-2 was weakly altered, manifesting the light-yellow green altered rims around phlogopite. The minettes are composed of pyroxene + micas $+\mathrm{K}$-feldspar \pm olivine \pm plagioclase \pm carbonates \pm apatite \pm Ti-Fe oxides, and the mineral assemblage of plagioclase-bearing minettes is pyroxene + micas + plagioclase \pm K-feldspar \pm carbonates \pm apatite \pm Ti-Fe oxides. The geologic setting of lamprophyres and sampling localities are illustrated in fig. 1.

Phlogopite separates from two lamprophyres were separated using a conventional isodynamic separator and handpicking under clean environmental conditions after sample washing and crushing. 8-10 mg phlogopite separates, with a purity better than 99\%, from samples LWZ-1 and LWZ-2, were wrapped in the Sn foil and sealed in 6-mm-ID evacuated quartz-glass vials together with Fish Canyon sanidine (FC-3) flux monitors, and irradiated in the Fort Reactor, University of Michigan. J-factors were determined by a laser ablation technique. The irradiated samples were step-heated in a tantalum crucible within a double-vacuum furnace and analyzed by a VG 3600 mass spectrometer at the University of California, Los Angeles. Argon blanks over the course of these analyses averaged $2 \times 10^{-16}-5 \times 10^{-16} \mathrm{~mol}{ }^{40} \mathrm{Ar}$ in an atmospheric ratio. The monitor standard was the FC-3 sanidine (27.8 Ma $\pm 0.3 \mathrm{Ma})$. All errors in table 1 are quoted at the 1-sigma level and do not include the uncertainty of the monitor age. The detailed analytical procedures were

Table1 Phlogopite ${ }^{40} \mathrm{Ar} /{ }^{39} \mathrm{Ar}$ dating data for two lamprophyres in the Laowangzhai gold deposit

\begin{tabular}{|c|c|c|c|c|c|c|c|c|c|c|}
\hline Step & $T /{ }^{\circ} \mathrm{C}$ & ${ }^{40} \mathrm{Ar} /{ }^{39} \mathrm{Ar}$ & $\begin{array}{c}{ }^{38} \mathrm{Ar} /{ }^{39} \mathrm{Ar} \\
\left(\times 10^{-2}\right)\end{array}$ & $\begin{array}{c}{ }^{37} \mathrm{Ar} /{ }^{39} \mathrm{Ar} \\
\left(\times 10^{-3}\right)\end{array}$ & $\begin{array}{c}{ }^{36} \mathrm{Ar} /{ }^{39} \mathrm{Ar} \\
\left(\times 10^{-3}\right)\end{array}$ & $\begin{array}{l}{ }^{39} \mathrm{Ar}(\mathrm{mol}) \\
\left(\times 10^{-14}\right)\end{array}$ & $\begin{array}{c}\text { Cumula- } \\
\text { tive }(\%)^{39} \mathrm{Ar} \\
\text { released }\end{array}$ & $\begin{array}{c}{ }^{40} \mathrm{Ar} * \\
(\%)\end{array}$ & $\begin{array}{c}{ }^{40} \mathrm{Ar}^{*}{ }^{\beta 9} \mathrm{Ar}_{\mathrm{K}} \\
( \pm 1 \sigma)\end{array}$ & $\begin{array}{l}\text { Apparent age } \\
( \pm 1 \sigma)(\mathrm{Ma})\end{array}$ \\
\hline \multicolumn{11}{|c|}{ LWZ-1 } \\
\hline 1 & 600 & 17.95 & 316.00 & 130.00 & 48.10 & 2.14 & 3.13 & 20.8 & $3.74 \pm 0.20$ & $46.1 \pm 2.4$ \\
\hline 2 & 700 & 3.550 & 8.04 & 28.50 & 2.55 & 3.92 & 8.86 & 77.7 & $2.77 \pm 0.07$ & $34.3 \pm 0.9$ \\
\hline 3 & 780 & 3.098 & 2.71 & 8.04 & 1.46 & 6.81 & 18.80 & 85.0 & $2.64 \pm 0.04$ & $32.7 \pm 0.5$ \\
\hline 4 & 850 & 3.044 & 2.70 & 5.42 & 1.44 & 8.37 & 31.10 & 84.9 & $2.59 \pm 0.03$ & $32.1 \pm 0.4$ \\
\hline 5 & 900 & 3.064 & 2.72 & 5.50 & 1.45 & 6.60 & 40.70 & 84.9 & $2.61 \pm 0.04$ & $32.4 \pm 0.5$ \\
\hline 6 & 950 & 3.049 & 2.67 & 4.39 & 1.52 & 8.81 & 53.60 & 84.2 & $2.57 \pm 0.03$ & $31.9 \pm 0.4$ \\
\hline 7 & 1000 & 3.066 & 2.71 & 4.79 & 1.64 & 9.84 & 68.00 & 83.2 & $2.56 \pm 0.03$ & $31.7 \pm 0.3$ \\
\hline 8 & 1150 & 2.798 & 2.56 & 5.33 & 1.08 & 21.90 & 100.00 & 87.6 & $2.45 \pm 0.02$ & $30.4 \pm 0.2$ \\
\hline \multicolumn{11}{|c|}{ LWZ-2 } \\
\hline 1 & 600 & 5.417 & 35.00 & 155.00 & 14.60 & 31.50 & 8.05 & 20.2 & $1.09 \pm 0.09$ & $13.7 \pm 1.1$ \\
\hline 2 & 750 & 3.163 & 2.28 & 191.00 & 3.07 & 20.50 & 13.30 & 70.8 & $2.24 \pm 0.03$ & $27.9 \pm 0.4$ \\
\hline 3 & 800 & 3.584 & 2.66 & 242.00 & 4.53 & 13.80 & 16.80 & 62.3 & $2.24 \pm 0.04$ & $27.9 \pm 0.5$ \\
\hline 4 & 850 & 3.751 & 2.80 & 377.00 & 4.88 & 18.70 & 21.60 & 61.6 & $2.31 \pm 0.03$ & $28.8 \pm 0.3$ \\
\hline 5 & 900 & 4.320 & 3.65 & 553.00 & 6.69 & 19.70 & 26.60 & 54.5 & $2.36 \pm 0.02$ & $29.4 \pm 0.3$ \\
\hline 6 & 950 & 3.776 & 3.09 & 265.00 & 4.75 & 24.00 & 32.70 & 62.6 & $2.37 \pm 0.02$ & $29.5 \pm 0.3$ \\
\hline 7 & 1000 & 3.552 & 3.48 & 154.00 & 4.49 & 26.00 & 39.40 & 62.2 & $2.21 \pm 0.03$ & $27.6 \pm 0.4$ \\
\hline 8 & 1100 & 3.964 & 5.38 & 543.00 & 4.50 & 47.50 & 51.50 & 66.8 & $2.65 \pm 0.01$ & $33.0 \pm 0.2$ \\
\hline 9 & 1200 & 4.203 & 5.29 & 694.00 & 4.88 & 179.00 & 97.10 & 66.3 & $2.79 \pm 0.01$ & $34.6 \pm 0.2$ \\
\hline 10 & 1350 & 4.849 & 4.64 & 386.00 & 8.09 & 11.30 & 100.00 & 50.4 & $2.46 \pm 0.17$ & $30.7 \pm 2.1$ \\
\hline
\end{tabular}

The J-factors for samples LWZ-1 and LWZ-2 are 0.006929 and 0.006955 , respectively. 
presented by ref. [8]. PGEs and Au were determined by ICP-MS using the isotope dilute method. The analytical procedures were after refs. $[9,10]$. PGEs are measured at the Institute of Geochemistry, the Chinese Academy of Sciences using Finnigan Mat Element ICP-MS. The blank over the course of the analyses is lower than $0.02 \mathrm{ng} / \mathrm{g}$. The detected values for standards UMT-1 and WGB are consistent with the certified values within analytical errors (table 2 ). The mean detecting limits are $\mathrm{Ir} 0.02, \mathrm{Rh} 0.024, \mathrm{Ru} 0.045, \mathrm{Pd} 0.11, \mathrm{Pt} 0.23$ and $\mathrm{Au} 0.32 \mu \mathrm{g} / \mathrm{g}$. The accuracies (\%) are $\mathrm{Ru}$ 6.5, Rh 6.1, Pd 2.2, Ir 3.5, Pt 1.5 and $\mathrm{Au}$ 2.5. The conventional acid solving method was adopted to solve the powder samples for $\mathrm{Ni}$ and $\mathrm{Cu}$ analyses. $\mathrm{Ni}$ and $\mathrm{Cu}$ were measured by $\mathrm{PE}$ Elan 6000 ICP-MS at the Guangzhou Institute of Geochemistry, the Chinese Academy of Sciences. Analytical uncertainties for $\mathrm{Ni}$ and $\mathrm{Cu}$ are better than 5\%. The analyzing procedures were given by ref. [11] in detail.

Table 2 Data of PGEs, $\mathrm{Cu}$, Au and Ni for lampropyres in the Laowangzhai gold deposit

\begin{tabular}{ccccccccccccc}
\hline & LNT-1 & DGL-2 & DGL-3 & LWZ-1 & LWZ-2 & DGL-1 & CH & PM & \multicolumn{2}{c}{ UMT-1 } & WGB-1 \\
\hline & LNT & DGL & DGL & LWZ & LWZ & DGL & & & CV & MV & CV & MV \\
$\mathrm{Cu}$ & 108.11 & 41.14 & 52.86 & 2.72 & 119.92 & 3.72 & & $2.8 \times 10^{4}$ & & & \\
$\mathrm{Au}$ & 40.5 & 37.6 & 60.1 & 80.3 & 61.1 & 52.6 & 152 & 1 & 48 & 55 & 2.9 & 3.3 \\
$\mathrm{Pd}$ & 5.93 & 3.49 & 5.16 & 4.07 & 6.12 & 2.09 & 545 & 4 & 106 & 108 & 13.9 & 14.6 \\
$\mathrm{Ru}$ & 1.64 & 2.49 & 1.09 & 1.13 & 0.28 & 0.25 & 690 & 4.3 & 10.9 & 10.8 & 0.3 & 0.34 \\
$\mathrm{Ir}$ & 2.35 & 1.82 & 1.03 & 4.34 & 2.75 & 2.79 & 540 & 3.6 & 8.8 & 8.4 & 0.33 & 0.37 \\
$\mathrm{Ni}$ & 73.72 & 98.99 & 70.99 & 94.8 & 99.23 & 174.67 & & $2.11 \times 10^{4}$ & & & \\
$\mathrm{Rh}$ & 1.31 & 1.19 & 0.65 & 0.25 & 0.31 & 0.29 & 200 & & 9.5 & 10.4 & 0.32 & 0.34 \\
$\mathrm{Pt}$ & 3.38 & 16.7 & 3.61 & 1.06 & 6.43 & 0.87 & 1020 & 7.5 & 129 & 124 & 6.1 & 6.55 \\
$\mathrm{Pd} / \mathrm{Ir}$ & 2.52 & 1.92 & 5.01 & 0.94 & 2.23 & 0.75 & 1.01 & 1.11 & & 0.53 & & \\
$\mathrm{Pd} / \mathrm{Pt}$ & 1.75 & 0.21 & 1.43 & 3.84 & 0.95 & 2.40 & 0.53 & 0.53 & \\
\hline
\end{tabular}

The data for $\mathrm{CH}$ (chondrite) and PM (primitive mantle) are quoted from refs. [12-14]. UMT-1 and WGB are two standards of Canadian Geological Survey. Ni and $\mathrm{Cu}$ are in $\mu \mathrm{g} / \mathrm{g}$. PGEs and Au are in $\mathrm{ng} / \mathrm{g}$. The abbreviations for the sampling localities are as follows: LNT, Lannitang; DGL, Donggualin and LWZ, Laowangzhai (fig. 1). CV and MV represent certified and measured values, respectively.

\section{Results}

Two phlogopite separates of two lamprophyres (LWZ-1 and LWZ-2) in the Laowangzhai gold deposit were step-heated to analyze the argon isotope compositions. The analytical result is presented in table 1. Their inverse isochrons and age plateaus are illustrated in figs. 2 and 3, respectively. We analyzed 8 steps for sample LWZ-1. An older apparent age (46.1 Ma $\pm 2.4 \mathrm{Ma})$ appears in step 1 , but the released ${ }^{39} \mathrm{Ar}(3.13 \%)$ and radiogenic ${ }^{40} \mathrm{Ar} *(20.8 \%)$ are relatively low (table 1). From steps 2 to 8 , their apparent ages gradually decrease, but the ages between the adjacent plateaus are identical within 2-sigma errors. Thus, the data of steps $2-8$ define an age plateau of $31.7 \pm 0.4 \mathrm{Ma}$ (fig. 2(b)). In the ${ }^{36} \mathrm{Ar} /{ }^{40} \mathrm{Ar}$ vs. ${ }^{39} \mathrm{Ar} /{ }^{40} \mathrm{Ar}$ diagram, all data yield a good inverse isochron of (30.8 \pm 0.4$)$ Ma with an initial ${ }^{40} \mathrm{Ar} /{ }^{36} \mathrm{Ar}$ ratio of 326.4 (fig. 2(a)). The higher initial ${ }^{40} \mathrm{Ar} /{ }^{36} \mathrm{Ar}$ ratio indicates the existence of excess argon. We consider that the older apparent age for step 1 may result from existence of excess argon in phlogopite. Owing to relatively rapid cooling after emplacement, the inverse isochron age for phlogopite (30.8 $\mathrm{Ma} \pm 0.4 \mathrm{Ma}$ ) may represent the 
intrusion age of lamprophyric magma.
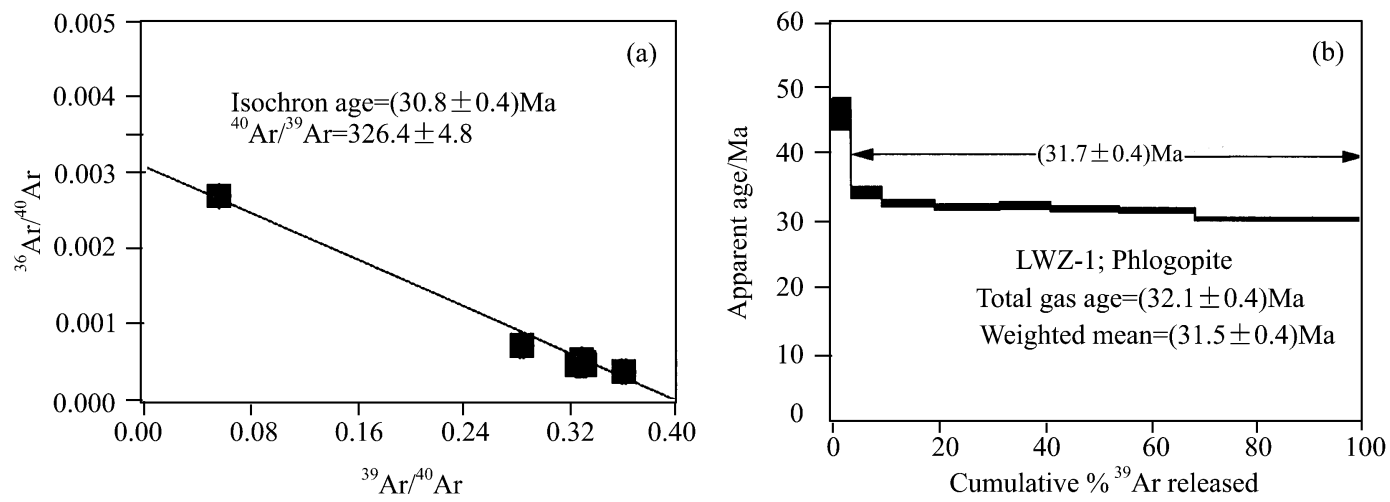

Fig. 2. Phlogopite ${ }^{40} \mathrm{Ar} /{ }^{39} \mathrm{Ar}$ isochron (a) and plateau (b) ages for a lamprophyre (LWZ-1) in the Laowangzhai gold deposit.
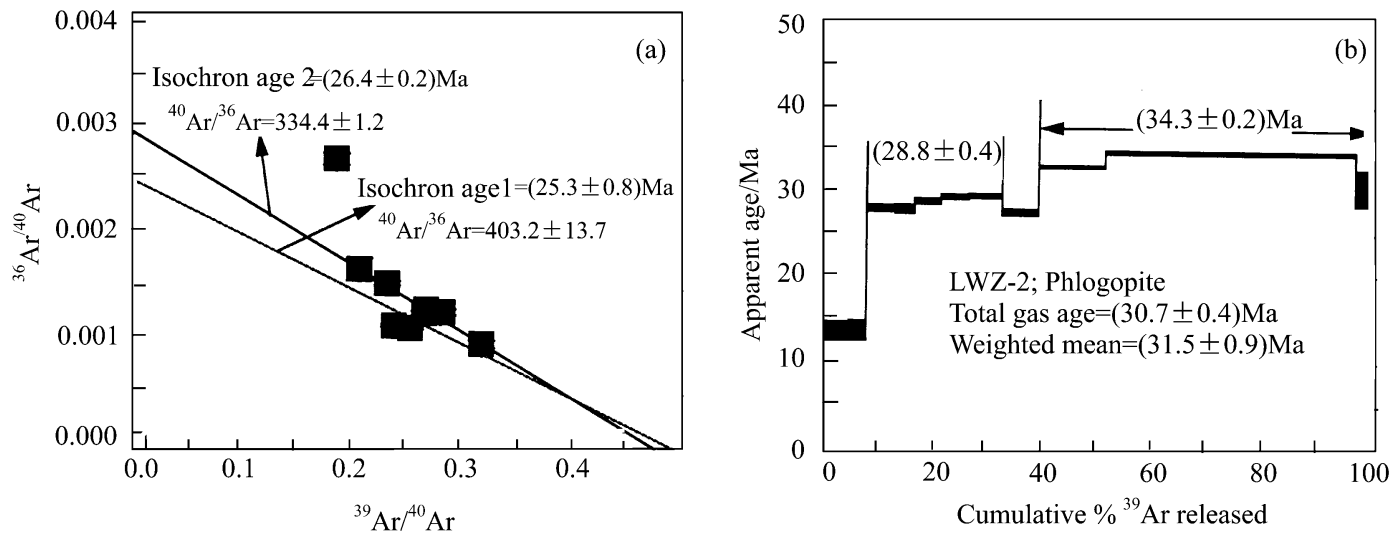

Fig. 3. Phlogopite ${ }^{40} \mathrm{Ar} /{ }^{39} \mathrm{Ar}$ isochron (a) and plateau (b) ages for a lamprophyre (LWZ-2) in the Laowangzhai gold deposit.

Ten steps were analyzed for sample LWZ-2, but the result is evidently different from that for sample LWZ-2 (fig.3). A very young apparent age (13.7 Ma $\pm 1.1 \mathrm{Ma}$ ) appears in step 1, but its released ${ }^{39} \mathrm{Ar}(8.05 \%)$ and radiogenic ${ }^{40} \mathrm{Ar}^{*}(20.2 \%)$ are relatively low (table 1$)$. The apparent ages of steps $2-6$ are identical within 2-sigma analytical errors. They yield a plateau age of $(28.8 \pm 0.4)$ Ma with $31.35 \%$ released ${ }^{39} \mathrm{Ar}$ (fig.3(b)), indicating that this age may reflect a later thermal event. The data of steps $2-7$ define an inverse isochron of $(26.4 \pm 0.2)$ Ma (fig.3(a)). The apparent ages of steps 8 and 9 are distinctly different from those of steps $2-7$. The data of steps 8 and 9 define a plateau age of $(34.3 \pm 0.2)$ Ma with $57.7 \%$ released ${ }^{39} \mathrm{Ar}$. This age may represent the crystallization time of phlogopite. Because of a low-released ${ }^{39} \mathrm{Ar}(2.90 \%)$ and high-error apparent age in step 10, the younger apparent age of step 10 may result from analytical errors. All data yield a relatively poor inverse isochron of $(25.3 \pm 0.8) \mathrm{Ma}$ with an initial ${ }^{40} \mathrm{Ar} /{ }^{36} \mathrm{Ar}$ ratio of 403.2 in the ${ }^{36} \mathrm{Ar} /{ }^{40} \mathrm{Ar}$ vs. ${ }^{39} \mathrm{Ar} /{ }^{40} \mathrm{Ar}$ diagram (fig. 3(a)). The higher initial ${ }^{40} \mathrm{Ar} /{ }^{36} \mathrm{Ar}$ ratio means the existence of 
excess argon trapped in phlogopite in sample LWZ-2, which may result in an age older than the actual time.

The data of PGEs, $\mathrm{Au}, \mathrm{Ni}$ and $\mathrm{Cu}$ data for six lamprophyres at Donggualin, Laowangzhai and Langnitang are presented in table 2. The total contents of PGEs except Os are characterized by a wide variational range from 6.29 to $25.69 \mu \mathrm{g} / \mathrm{g}$. The ratios of $\mathrm{Pd} / \mathrm{Ir}(0.94-5.01)$ and $\mathrm{Pd} / \mathrm{Pt}(0.21-$ 3.84) for lamprophyres are higher than those for the primitive mantle and chondrite. The PGE patterns normalized by chondrite ${ }^{[11]}$ and primitive mantle ${ }^{[12,13]}$ are flat (fig. 4), slightly depleted in $\mathrm{Ru}$ (fig.4(a)) and weakly negatively anomalous in Pt and Ru (fig. 4(b)). The clearly positive Au anomaly appears in the PGE patterns (fig. 4). The gold contents in lamprophyres are $38-81$ times as much as that in the primitive mantle, but the contents of $\mathrm{Cu}$ and $\mathrm{Ni}$ are different from that of $\mathrm{Au}$, showing an obvious depletion (fig.4(a)), e.g. the contents of $\mathrm{Cu}$ and $\mathrm{Ni}$ are only $3.86 \times 10^{-3}$ $9.71 \times 10^{-5}$ and $3.36 \times 10^{-5}-8.28 \times 10^{-5}$ times as much as those in the chondrite and primitive mantle, respectively. No correlation between PGEs appears in the lamprophyres.
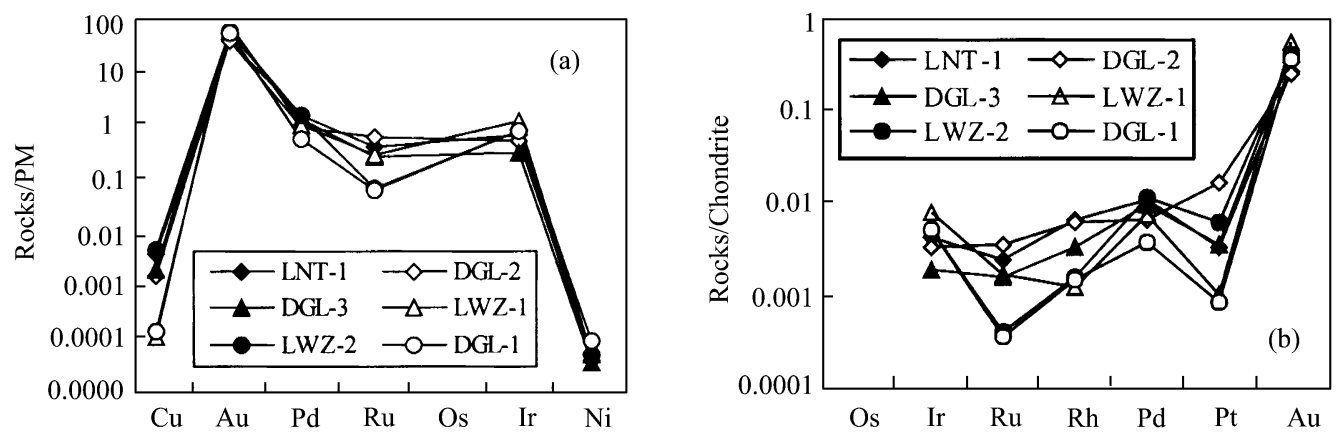

Fig. 4. PGE patterns for lamprophyres, normalized by the primitive mantle (PM) (a) and chondrite (CH) (b).

\section{Discussion and conclusion}

\subsection{Ages of lamprophyre intrusion and gold mineralization}

In order to avoid influence of excess argon in two phlogopite separates of samples LWZ-1 and LWZ-2, the isochron ages were adopted to discuss geologic problems. Obviously, the isochron age of $(30.8 \pm 0.4)$ Ma for sample LWZ-1 may represent the emplacement time of the lamprophyres. Although no consistent plateau age is obtained in sample LWZ-2, the result is still useful. The plateau age of $28.8 \pm 0.4 \mathrm{Ma}$ for steps $2-6$ may reflect an important later thermal event, which reset phlogopite in the lamprophyre. Owing to the existence of excess argon, its actual time may be slightly younger than the plateau age. Thus, the inverse isochron age of $(26.4 \pm 0.2)$ Ma for steps $2-7$ (fig.3(a)) may represent the time of this later event.

Combined with the characteristics of altered phlogopite in mineralized lamprophyres and the close paragenesis between lamprophyres and gold ores, we think that this important thermal event should be a widespread mesothermal alteration associated with gold mineralization after em- 
placement of lamprophyres. Hydrothermal alteration (i.e. addition of a mineralizer) and gold mineralization took place at the age of $(26.4 \pm 0.2) \mathrm{Ma}$, which is the same as the previous apatite FT ages $(22.7 \mathrm{Ma}-27.1 \mathrm{Ma})^{[2]}$. The plateau age of $(34.3 \pm 0.2)$ Ma for sample LWZ-2 may represent the maximum emplacement time of lamprophyres in this area.

3.2 PGE geochemical discrimination between primitive and secondary enrichment of gold in lamprophyres

Rock et al. ${ }^{[15,16]}$ proposed a genetic model for mesothermal gold deposits. In this model, the higher gold abundance in lamprophyres was interpreted as a product of metasomatism of mantle plume fluids. Wyman et al. ${ }^{[17]}$ considered that addition of gold to the later alteration induced strong enrichment of gold in lamprophyres. Actually, the main periods of lamporphyric activities are inconsistent with the time intervals of thermal pulses induced by large-scale mantle plumes, and usually related to the time of regional orogenic and tectonic movements. The elemental geochemical tracing also obviously shows that emplacement of lamprophyric magma is related to the geologic processes in the shallow upper mantle, and associated with subduction ${ }^{[17,18]}$. The previous elemental and isotopic data ${ }^{[2,21]}$ indicate that the lamprophyres originating from an EM2 mantle source is related to subduction.

In the mantle magma processes, the geochemical behavior of gold, $\mathrm{Pt}$ and $\mathrm{Pd}$ is controlled by sulfur, due to very large partition coefficients between sulfur and gold or PGEs. If sulfur is under-saturated, Au, Pt and Pd enter magma and manifest incompatible elements. Conversely, if sulfur is over-saturated, Au, Pt and Pd stay in the sulfides as compatible elements. Sun et al. ${ }^{[13]}$ indicated that mafic-ultramafic magma with under-saturated sulfur and Au-, Pt- and Pd-rich may be produced in two ways. One is high-melt-fraction partial melting of an MORB-type asthenospheric mantle at high temperature. The other is low-melt-fraction partial melting of a refractory mantle from which a large amount of magma had been extracted in low-temperature alteration and water addition. In fact, the low-Ti lamprophyres discussed by Rock et al. ${ }^{[15]}$ is a product of secondary partial melting of a refractory mantle wedge in the subduction zone. If partial melting takes place in an abnormal mantle rich in Au, PGEs and sulfides, Au and PGEs are not enriched in the produced partial melt, for they are preserved in sulfides as components of the remnants. Because Au, $\mathrm{Pt}$ and Pd have similar chalcophile behavior in the mantle magma processes, the secondary or primitive enrichment of gold in magmatic rocks can be discriminated by correlation between $\mathrm{Au}$ and $\mathrm{Pt}$ or $\mathrm{Pd}$. In the patterns normalized by the primitive mantle, enrichment of $\mathrm{Cu}, \mathrm{Pt}$ and $\mathrm{Pd}$ follows primitive enrichment of gold, showing a positive correlation between $\mathrm{Au}$ and $\mathrm{Cu}, \mathrm{Pt}$ or $\mathrm{Pd}$. The patterns in fig.4(a) are characterized by evident enrichment in Au (higher positive anomalies in $\mathrm{Au}$ ), depletion in $\mathrm{Cu}$ and no enrichment in $\mathrm{Pd}$. The patterns in fig.4(b) are characteristic of positive anomalies in Au relative to PGEs, which is clearly different from those for Pt and Pd. No positive correlation between $\mathrm{Au}$ and $\mathrm{Ni}, \mathrm{Cu}, \mathrm{Pt}$ or Pd appears in the omitted variational diagram. Obviously, gold in the lamprophyres in the Laowangzhai gold deposit was secondarily enriched, 
and did not come from the paragenetic lamprophyres. The evidence from tracing of fluid and isotopic geochemistry ${ }^{[4]}$ also supports this conclusion.

Although defects in the theory and data citation exist in Rock et al.'s model ${ }^{[15,16]}$, they emphasized the fact that lamprophyres were closely tempo-spatially associated with mesothermal gold deposits. Then, a question follows: what does the tempo-spatial association mean? Most of global lamprophyres associated with mesothermal gold deposits are shoshonitic. Phanerozoic shoshonitic rocks usually form in the post-collisional transpressional setting, and are related to subduction. The large-scale post-collisional compressional shear zone is the most important location to reserve mesothermal gold deposits. The shoshonitic volcano-intrusive complexes coeval with the lamprophyres in the Laowangzhai gold deposit are widely distributed along the Jinsha-Red River belt ${ }^{[19]}$. They have similar elemental and isotopic geochemical characteristics (such as low Ti, high $\mathrm{K}$, shoshonitic-ultrapotassic series, enrichment in LILEs and LREEs, evidently negative anomalies in $\mathrm{Nb}$ and $\mathrm{Ta},{ }^{87} \mathrm{Sr} /{ }^{86} \mathrm{Sr}=0.705-0.709$ and ${ }^{143} \mathrm{Nd} /{ }^{144} \mathrm{Nd}<0.5126$ ), similar magmatism time $(42-28 \mathrm{Ma})$ and identical tectonic setting (local extension in transpression) ${ }^{[19]}$. Thus, we consider that the same tectonic setting is the reason why lamprophyres are closely tempospatially associated with mesothermal gold deposits at the Laowangzhai in the Ailao Shan belt as well.

\subsection{Conclusion}

It is concluded that the emplacement age of lamprophyric magma in the Laowangzhai gold deposit ranges from $(30.8 \pm 0.4)$ to $(34.3 \pm 0.2) \mathrm{Ma}$, and gold mineralization may occur at the age of $(26.4 \pm 0.2)$ Ma. The PGE geochemistry indicates that gold in lamprophyres in the Laowangzhai gold deposit is secondarily enriched, lamprophyres cannot provide gold mineraization of the Laowangzhai gold deposit with gold, and the close tempo-spatial paragenesis between shoshonitic igneous rocks (including lamprophyres) and mesothermal gold deposits may be attributed to the fact that they formed in the same tectonic setting.

Acknowledgements This work was supported by the Chinese National Key Project for Basic Research on Tibetan Plateau (G1998040800), the National Natural Science Foundation of China (Grant Nos. 49972026, 49472100), the National Climbing Project (95-Y-25), CAS's Projects (KZCX2-101, KZ952-J1-408) and US-NSF Project.

\section{References}

1. He, W. J., Characteristics of the lamprophyres and their relations to gold mineralization in the Zhenyuan gold deposit field, Yunnan Geology (in Chinese), 1993, 12(2): 148-158.

2. Huang, Z. L., Liu, C. Q., Zhu, C. M., The origin of lamprophyres in the Laowangzhai gold filed, Yunnan Province and Their Relations with Gold Mineralization (in Chinese), Beijing: Geological Publishing House, 1999. 1—251.

3. Bi, X. W., Hu, R. Z., He, M. Y., ESR ages and their geologic significance in the Ailao Shan gold deposit belt, Chinese Science Bulletin, 1996, 41(14): 1301-1303.

4. Hu, R. Z., Bi, X. W., He, M. Y., Mineralizer constraining the gold mineralization in the Ailao Shan gold-deposit belt, Science in China, Series D, 1998, 28(Suppl.): 24-30.

5. Zhang, Z. L., Zhang, S. F., Yuan, H. H. et al., An isotope geology and origin study of the Jinchang gold deposit, Mojiang, Yunnan, Journal of Chengdu College Geology (in Chinese), 1987, 14(4): 29 - 41. 
6. Geyh, M. A., Schleicher, H., Absolute Age Determination: Physical and Chemical Dating Methods and Their Application, Berlin: Springer-Verlag, 1990. 272-282.

7. Huang, Z. L., Zhu, C. M., Xiao, H. Y. et al., Can a lamprophyric magma carry gold up? The evidence from a high- $T$ and high- $P$ experiment, Chinese Science Bulletin, 1999, 44(12): 1331-1334.

8. Harrison, T. M., Chen, W. J., Leloup, P. H. et al., An early Miocene transition in deformation regime within the Red River fault zone, Yunnan, and its significance for Indo-Asian tectonics, Journal of Geophysical Research (in Chinese), 1992, 97: $7159-7182$.

9. Gregoire, D. C., Determination of platinum, palladium, ruthenium and iridium geological materials by inductively coupled plasma mass spectrometry with sample introduction by electrothermal vaporization, Journal of Analytical Atomic Spectrometry, 1988, 3: 309-314.

10. Qi, L., Deng, H. L., Hu, J., Determination of precious metal elements in geological samples by isotope dilute inductively coupled plasma mass spectrometry, Yunnan Chemical Engineering (in Chinese), 1998, (Suppl.): 94—96.

11. Liu, Y., Liu, H. C., Li, X. H., Simultaneous and precise determination of 40 trace elements in rock samples using ICP-MS, Geochimica, 1996, 25(6): 552-558.

12. Naldrett, A. J., Duke, J. M., Platinum metals in magmatic sulfide ores, Science, 1980, 208: 1417—1424.

13. Sun, S. S., Chemical composition and origin of the earth's primitive mantle, Geochimica et Cosmochimica Acta, 1982, 46: $176-192$.

14. Brugmann, G. E., Arndt, N. T., Hoffmann, A. W. et al., Nobel metal abundances in komatiite suites from Alexo, Ontario and Gorgona Island, Colombia, Geochimica et Cosmochimica Acta, 1987, 51: 2159-2169.

15. Rock, N. S. M., Groves, D. I., Can lamprophyres resolve the genetic controversy over mesothermal gold deposit? Geology, 1988, 16: 538 - 541 .

16. Rock, N. S. M., Groves, D. I., Perring, C. S. et al., Gold, lamprophyre and porphyries: what does their association mean? Economic Geology, 1989, 6: 609-625.

17. Wyman, D. A., Kerrich, R., Archean shoshonitic lamprophyres associated with superior province gold deposits: Distribution, tectonic setting, noble metal abundances, and significance for gold mineralization, Economic Geology, 1989, 6: $651-667$.

18. Sun, S. S., Wallace, D. A., Hoatson, D. M. et al., Use of geochemistry as a guide to platinum group element potential of mafic-ultramafic rocks: examples from the west Pilbara and Halls Creek mobile zone, western Australia, Precambrian Research, 1991, 50: 1-35.

19. Wang, J. H., Yin, A., Harrison, T. M. et al., A tectonic model for Cenozoic igneous activities in the eastern Indo-Asian collision zone, Earth and Planetary Science Letters, 2001, 188: 123-133. 